\title{
Strategy for Developing Tourism Based Creative Economic in Supporting the Economy of Rote Ndao- East Nusa Tenggara Regency
}

\author{
Selfisina Samadara, J. S.Sir, M.Siahaan \\ \{selfisamadara@gmail.com, jenniesarlotasir@gmail.com,m.siahaan@gmail.com\} \\ Politeknik Negeri Kupang, Indonesia
}

\begin{abstract}
The subjects of this research are the government, the community, creative industry business owners, and tourists. Data collection techniques used are interviews, observation, and documentation. Data were analyzed using quantitative and qualitative descriptive analysis and SWOT analysis. The results showed aspects of developing a creative economy based on tourist attractions in Rote Ndao Regency; Aspects of creative economic potential such as marine tourism, traditional ceremonies, arts, Sasando craft forms, weaving and folklore. The main problems that become weaknesses and threats include; aspects of infrastructure in the field of tourism that are still limited and even some are not yet available, whereas, aspects of low accessibility due to poor road conditions, limited facilities; limited transportation infrastructure to tourist sites, as well as the lack of maximum promotional efforts and the unavailability of Tourist Information Center (TIC). Strategies and programs for developing the Creative Economy that need to be carried out in Rote Ndao Regency include: (a) Structuring marine tourism areas, (b) Improving the Quality of the Environment, Enhancing the Quality of Social and Cultural Life of the Community, Increasing the quality of creative industry products, (c) Increasing promotion tourism by the Rote Ndao District Tourism and Culture Office, Cooperation with the Travel Bureau (BPW), Provision of Tourist Information Center (TIC), and (d) Improvement of human resources.
\end{abstract}

Keywords: strategy, economy, creative, economy

\section{INTRODUCTION}

The main capital in facing the globalization era is activity. To form a unique added value, it is necessary to have the appearance of a creative economy, so that it can create markets in the global world. Globalization and global trade is an inevitable matter of technological progress. In the context of globalization, competitiveness is the main key to success and survival. This competitiveness appears not only in the form of many products but also quality. High creativity is needed to be able to create innovative products. Departing from this point, the creative economy finds its existence and develops [1].

Tourism and the creative economy are two things that influence each other and can work together if managed properly. The concept of tourism activities can be defined by three factors, namely there must be something to see, something to do, and something to buy. Something to see is related to attractions in tourist destinations, something to do is related to tourist activities in tourist areas, while something to buy is related to typical souvenirs purchased in tourist areas as personal memorabilia of tourists. In these three components, the creative economy can enter 
through something to buy by creating innovative products that are specific to the region. The strength of building creative industries is largely determined by the collaboration of three main actors, namely intellectuals, business and government, which are then called the triple helix system. These three actors are the drivers of creativity, ideas, science and technology which are vital for the growth of the creative industry.

The development of the creative economy is inseparable from the culture of the local community. The development of the creative economy must be based on the culture of the local community. The culture of the local community is local wisdom that must be preserved and developed in an integrated form in every development activity. Local wisdom in ordinary culture in physical and non-physical forms. Local wisdom in physical and non-physical forms can be products that have meaningful values such as craft, art, culinary, and others. Creative economy is not only measured in economic terms but can also be measured in terms of cultural dimensions. Today, the creative ideas that arise basically come from local local wisdom. This gives meaning that local wisdom really determines the direction of the development of the creative economy in Indonesia. The creative economy that is developed by paying attention to local wisdom is an alternative solution that can encourage the development of the creative economy to become more independent, especially in the regions. Where, regions have products that reflect their respective cultures. Like local wisdom in Rote Ndao Regency can support the tourism sector in this area. Like local wisdom in Rote Ndao Regency can be a tourist attraction. Based on the Vision of the Rote Ndao District: The realization of the Rote Ndao Community that is dignity rests on Tourism Development supported by Agriculture and Fisheries, the Rote Ndao Regency is a Tourist Destination Region (DTW). Data obtained at the Tourism Office of the Rote Ndao Regency, tourist visits to the Rote Ndao Regency for 5 (five) years from 2013 to 2018 always experience an increase.

This study will analyze the aspects that affect specifically aspects of the potential for the realization of a tourist area, accessibility aspects, and aspects of amenities in terms of its existence as a tourism support. Furthermore, it will also be presented strategies and programs for developing a creative economy based on tourist attraction. The purpose of this study are; (1) to analyze aspects of tourism-based creative economy (2) to formulate tourism-based creative economy development strategies and programs in Rote Ndao district

\section{FORMULATION OF THE PROBLEM}

Based on the description above, the formulation of the problem in this study:

1. What is the aspect of tourism-based creative economy in supporting the economy of Rote Ndao district?

2. What is the tourism-based creative economy development strategy and program in Rote Ndao district?

\section{LITERATURE REVIEW}

\section{Definition of creative economy}

Creative Economy According to the Indonesian Republic of Indonesia's Ministry of Commerce in 2008, Creative Economy is an added value based on ideas born from the creativity 
of human resources (creative people) based on science, including cultural and technological heritage. In the creative economy, innovation cannot be separated from creativity because creativity is the driving factor for the emergence of new inventions (innovations) or utilizing existing inventions. The creative economy can not only be consumed by end consumers but can also be utilized by other sectors. Creative economy can encourage sustainable economic growth. This is because the resources of the creative economy can always be updated. According to John Howkins [2].

\section{The impact of the creative economy}

The creative economy needs to be developed because in general the creative economy has a positive impact on a country's economy. The impact of the creative economy is as follows: 1 . Provide a positive impact in the economic field. The economic impacts are: a. Increased Gross Domestic Product (GDP) b. Employment opportunities c. Increased production 2. Social impacts In the social sector, the economy has the following impacts: a. Quality of Life b. Social Tolerance c. Reducing Social Inequality.

\section{Local culture}

Based on Law Number 32 of 2009 concerning Environmental Protection and Management, local wisdom is the noble values that apply in the way of life of the community. Characteristics of local wisdom can be in the form of a legacy of civilization carried on for generations, considered capable of controlling various influences from outside, concerning values and morals in the local community, unwritten but still recognized as wealth in various legal perspectives, and forms of traits attached to someone or groups based on their origin. The development of a creative economy based on local wisdom is the concept of developing the natural, cultural, and cultural potentials of the local community. The community participates directly in it so that little by little a community's creativity will be created in developing tourist attraction as a source of income in improving their welfare

\section{Definition of Tourism Object}

One of the elements that determine the development of the tourism industry is tourism and tourist attractions. In short, tourism products with tourism objects and tourist attractions seem to have the same understanding, but actually have differences in principle [3]. An area to become a good Tourist Destination Region must be developed 3 (three) things so that the area is interesting to visit, namely:

1. There is something to see

The point is something interesting to see.

2. There is something to buy

The point is something interesting and unique to buy.

3. There is something to do

The point is something that can be done in that place.

The three things above are strong elements for the tourist destination while for the development of a tourist destination there must be a number of things that must be considered [4], including:

1. Must be able to compete with existing tourist objects and similar to attractions in other places.

2. It must be permanent, unchanging and immovable except from the field of development and development. 
3. Must have adequate facilities and infrastructure and have its own characteristics.

4. Must be interesting in general terms (not the understanding of subjective) and aware of the local community tourism.

\section{RESEARCH METHODS}

\section{Research Subjects and Objects}

The subjects of this study are the government, the community, creative industry business owners, and tourists. The object of this study is the Tourism-Based Creative Economy Development Strategy in Supporting the Economy of Rote Ndao-East Nusa Tenggara Regency.

\section{Data Types and Sources}

The data used in this study are primary data. Primary data is obtained through interviews, observations, and documentation.

\section{Method of collecting data}

The primary data obtained by the author in this study is to use a questionnaire, namely data collection techniques by giving a list of written questions to respondents. Questionnaire about the creative economy and tourism. Questionnaires were distributed by visiting and distributing questionnaires directly to the public, creative industry business owners, and tourists. Data were analyzed using quantitative and qualitative descriptive analysis and SWOT analysis.

\section{Population and Sample}

The population used in this study is the community, creative industry business owners, and tourists.

\section{Operational Definition and Variable Measurement}

The research variable is basically everything in the form of whatever is determined by the researcher to be studied in order to obtain information about it, then conclusions are drawn [5]. The variable used in this study is the Tourism-Based Creative Economy Development Strategy in Supporting the Economy of Rote Ndao-East Nusa Tenggara Regency.

\section{RESULTS AND DISCUSSION}

\section{Rote Ndao Tourism District}

Tourism is one of the areas whose development is prioritized by the Rote Ndao Regency Government. This is clearly seen in the Vision and Mission of the Rote Ndao District in 2015-2019, with the Vision: Realization of a Rote Ndao Community that is Supreme based on Tourism Development supported by Agriculture and Fisheries. Mission: Building Tourism Facilities \& Infrastructure; Support the development of tourist attractions; Developing Tourism Resources; Develop Cross-Sector Cooperation; Building an Information Network System and Promotion of Tourism; Improving the Quantity and Quality of HR as well as tourism institutions. Developing environmentally friendly tourism. 
The following are a variety of natural and cultural tourism objects on the island of Rote which are recorded based on the district area as follows:

1. Landu Leko District

There are 10 attractions in Landu Leko sub-district: Dead Sea, Lake Oendui, Mouth of a Thousand, Kainadi Beach, Mae'oe Beach, Tanjung Pukuafu, Nisita, Usu Island, Bird's Nest Cave, Ledulu Lake

2. Rote Timur District

There are 5 places in East Rote sub-district: Oesosole Beach, Fei Bay, Bajo Beach, Solokaelutu Beach, Mount Lakamola

3. Pantai Baru District

There are 10 attractions in Pantai Baru sub-district: Batu Ndao Beach, Raja Lelenuk Fortress, Niak Cave, Letediu, Nusakdale Beach, Oeledo Beach, Namohodale Beach, Oeo, Nita, Benteng Benteng

4. Rote Tengah District

There are 9 attractions in Rote Tengah subdistrict, namely: Termanu Stone, Sosadale Beach, Batu Ofak, Peto Lake, Oeleak, Sanilai, Leli Beach, Kaden Spring, Fopo Bea

5. Lobalain District

There are 9 attractions in Lobalain sub-district namely: Flagpole, Three Hundred Stairs, Old Religion Church, An-Nur Mosque, Raja Rote House, Namo Ndao Crafts Center, Japanese Cave, Oemau Bath, Dombo Beach

6. Rote Selatan District

There are 12 attractions in South Rote sub-district namely: Expansion of the Kite, Batu Intan Cave, Saina Cave, Mount Ingulai, Masi Dae Beach, Tanjung Nggolo, Nasedale Beach, Sailulik, Stone Age Chair, Lake Seda, Lake Bisak, Nituk City,

7. District. Northwest Rote

There are 3 attractions in Rote Barat Kecamatan, namely: Raja Dengka House, HUS Culture, Oeseda Beach.

8.Southwest Rote District

There are 9 places of tourist attractions in Southwest Rote District: Raja Thie's house, Fiulain, Oeseli Beach, Oebou Beach, Ndana Beach, Sanama Beach, Danau Tua, Nusa Manuk Beach, Utak Island

9. West Rote District

There are 7 attractions in West Rote Subdistrict: Bo'a Beach, Nemberala Beach, Lake Oehela, Tongga Beach, Rua Bafa Rua Cave, Tara Ndola Cave, Tene Oen Cave 10.Ndao Nuse District

There are 7 attractions in Ndao Nuse Subdistrict: Do'o Island Beach, Ndao Island Beach, Nuse Island Beach, Duyung Cave, VOC Cannon, Ndao Nuse Marine Park.

A prominent tourist attraction in this archipelago is the beach tourism. Rote Island has so many beaches, almost all districts have beaches. Of all the beaches in Rote, Nembrala Beach and Thousand Mouth Beach are the beaches that are most sought after by foreign parties. Nemberala Beach is very similar to Kuta Beach in Bali. In that place there is a stretch of white sand with clear, clear sea water. If the weather is sunny and the sun rises from the south, you will see the black shadows of the Australian Continent. Nembrala Beach has waves that are very suitable for surfers. In September every year national and international surfing festivals are held at this beach. Thousand Mouth Beach found in Kec. East Rote, Kab. Rote Ndao is very beautiful with a marine park and pearl cultivation. For people / tourists who have just visited the mouth of a thousand, always have difficulty or get lost when exiting, it is very tortuous that it is said 
that there is a master who keeps closing the exit when guests enter do not ask permission from the owner.

Sasando is a traditional musical instrument that is very typical of palm leaves. Sasando music is picked to accompany Rote Regional songs and other national songs. This tool is usually played in a variety of important social activities such as marriage, death, birth, and birthdays. In addition to the existing culture, the people of Kab. Rote Ndao also has a unique culture. Among them are the Belote "Tu'u" Belis Culture, Traditional Traditional Ceremony (HUS) and the tradition of foot striking.

Rote culture "Tu'u" Belis is a culture that has been running for hundreds of years, death and marriage on Rote Ndoa Island, East Nusa Tenggara, is a revelry. Ndeo Traditional Traditional Ceremony (HUS) in Boni Village, Kec. North West Rote, is a competition of skills and test of horse riding and the tradition of footwork. This HUS Ceremony is carried out every year from July to September to worship the Almighty God and the ancestors who contributed to the rain's blessing for the Rote Ndao area. In one of the Hus rituals, the elders ask for rain from the gods with a ritual (songgo), called the kalapa (coconut) ritual. Another cultural attraction is the tradition of striking, at Tesabela Village, Pantai Baru District, Rote Island. Not many people know about the existence of this tradition, where the calf will be wrapped around Rote woven fabric and then be dirotani or beaten while cheered by the audience. Not only traditions, rituals and traditional ceremonies, but also the language of the Rote region which consists of many variations of dialects is rarely used

With so much natural, artistic and cultural potential possessed by Rote Ndao regency, it should be able to become a source of PAD for Rote Ndao regency and be able to prosper the people of Rote island so that the vision of Rote Ndao regency for the realization of the Rote Ndao community which is digtny rests on Tourism Development supported by Agriculture and Fisheries can be achieved. To make Rote Ndao Regency as a tourist destination for domestic and international tourists, it must be followed by good management and introduction to the public effectively and efficiently. If the tourist attraction increases, it will have an impact on increased revenue so that there is no difficulty in covering the costs used for operational attractions. Therefore, it is very important to formulate a strategy for developing creative economics that is appropriate, effective and efficient. Based on the results of an analysis of aspects of the potential for the development of tourism-based creative economy, it shows that the aspects of structuring marine tourism areas with an average value of 4.5 (very supportive) and accessibility aspects with a mean value of 2.0 (less supportive) as well as aspects of facilities and infrastructure with the mean value is 2.0 (less support).

\section{External environment}

Based on the SWOT analysis in particular Opportunities that can be potential and can also be a threat in the development of a creative economy based on local wisdom in supporting Tourism Attraction, namely; (1) The vision of Rote Ndao Regency to realize the Rote Ndao Community whose dignity rests on Tourism Development, (2) There is an increase in the number of domestic and foreign tourist visits from year to year, (3) Has high competitiveness with other regions that have contractions similar tours.

\section{Threats}

(treats) are: (1) Facilities and transportation infrastructure are still inadequate so that access is still difficult to reach (2) The absence of an information system in Rote Ndao Regency which is oriented to the area profile that is tourism promotion 


\section{Internal environment}

In addition to the external environment, the internal environment is also a key part of the SWOT analysis which outlines various impacts that will arise from within [6], namely the strengths and weaknesses of Rote Ndao District. This, greatly affects the development of the creative economy as a support for the Tourism Attraction. There are key points regarding strengths and weaknesses of Rote Ndao Regency, as described below.

\section{Strength}

The strengths of Rote Ndao Regency include; (1) Having natural and exotic natural beauty and panoramas, (2) Having traditional ceremonial nuances, (3) Cultural uniqueness of the local community, (4) The existence of unspoiled tourism attractions with regional characteristics, (5) Having industrial products creative products, especially the folk handicraft industry, (6) The existence of government policies and the support of the local community is very large in the development of tourism.

\section{Weaknesses.}

The weaknesses of the Rote Ndao Regency are; (1) Limited transportation infrastructure, (2) Access to location is still difficult to reach, (3) Tourism facilities are still limited or not available, (4) Housing facilities and infrastructure are still limited, (5) Limited budget from local governments in developing tourist attractions, (6) Limited human resources, (7) There is no management of tourist attractions, (8) Not yet maximum promotional efforts, (9) Not yet available Tourist Information Center (TIC).

\section{Strategy and Program for Creative Economy Development}

Strategies for developing a creative economy based on local wisdom in supporting Tourism Attraction in Rote Ndao Regency include:

(1) SO (Strength Opportunity) strategy, which is a strategy that uses power to take advantage of opportunities, generating strategies for developing accessibility and infrastructure [7]

(2) Strategies for ST (Strength) Threat) is a strategy that uses strength to overcome threats, produces creative economic development strategies based on local wisdom in supporting sustainable tourism attraction,

(3) WO (Weakness Opportunity) strategy, which is a strategy that minimizes weaknesses to take advantage of opportunities, produces a strategy to develop tourism promotion, and

(4) WT (Weakness Threat) Strategy which is a strategy that minimizes weaknesses and avoids threats resulting in a Human Resources (HR) development strategy.

The tourism-based creative economic development program in Rote Ndao Regency includes:

1) Development Program of SO (Strengths - Opportunities) Strategies. From the SO strategy (Accessibility and Infrastructure Development Strategy) the Rote Ndao Regency tourism management program was formulated. There are several programs referred to as explained below.

- Development and improvement of infrastructure in tourist areas. To support the growth and development of the region as a Tourist Attraction. Infrastructure aspects are also a necessity to serve tourists. The facilities that already exist in the study location but still need to be improved are food and drinking kiosks, kiosk / restaurant parking lots, and public toilets. And facilities that are not yet available at the study location, among others; hotel / inn, 
security post, first aid post, souvenir shop, gallery, staging tourist attractions, restaurants, tourist information center

- Road construction and improvement (accessibility). Accessibility is also an influential aspect in the growth and development of the region in providing facilities and smooth activities. Study locations based on accessibility aspects have low access in the sense that they are still difficult to reach. This can be seen from the existence of existing transportation facilities and infrastructure such as; the quality of the highway to tourist attractions, the width of the road body that has not or is not in accordance with the standards of the highway and the access road, limited traffic signs and road markings, as well as the type of transportation to the study location is still very limited.

2) Development Program of the ST Strategy (Strengths - Treats)

The development program of the ST strategy is a creative economic development strategy based on sustainable local wisdom [8]. The concept of sustainable development is the process of developing creative economic potential that does not exclude the resources possessed for future development. For this reason, the development of the tourism area of Rote Ndao Regency still pays attention to important aspects, namely economic sustainability, the physical environment of the region, and culture as an important resource in tourism development. The development program that can be carried out, as explained below.

-Improved Environmental Quality. The environment is a very vital factor in the development of tourism [9] Environmental damage caused by tourism will require a very long time to return to normal. There are several implementation programs that can be carried out in preventing the occurrence of environmental damage, namely: (1) Clean environmental culture. Building an environmentally friendly community culture that can be done through measures of supervision, guidance and management of the environment both from government and community elements. The things that need to be done by government elements are to socialize Law Number 32 of 2009 concerning Environmental Protection and Management to the public and industry, including prohibitions and sanctions for anyone who clearly commits environmental destruction. Meanwhile, from the elements of the community empowering environmental management, (1) Strict rules from the government for environmental management. Conduct various counseling to the community in an effort to build and raise awareness

-Improving the Quality of Community's Social and Cultural Life. The social and cultural life of the people in the Rote Ndao District tourism area should be able to be further improved in order to realize an improvement in the quality of the socio-cultural life of the people.

Things that need to be done include:

(1) Making local culture a tourist attraction. Culture is the most important thing for tourism in the Rote Ndao District.

(2) Adjustment of the rules of the customs and habits of the community with the development of time.

(3) Organizing cultural events.

(4) Improvement of Community Economy. The benefits derived from the development of tourist attractions both directly and indirectly will open up job opportunities and business opportunities. Some things that can be done include: (1) The government helps provide facilities to obtain business capital loans to people who want to open a business. This is so that it can indirectly stimulate community interest in entrepreneurship, especially for people who do not have permanent jobs; (2) The government and tourism actors work together to provide understanding and socialization to the public about what efforts can be done to seize opportunities that exist; and (3) Providing coaching and training to the community so that they can be guides / guides 
for tourists who come and various other opportunities that need to be explored continuously but still pay attention to aspects of resource sustainability.

\section{3) Development Program of the WO Strategy (Weaknesses - Opportunities)}

The program that can be carried out in promoting the tourism area in Rote Ndao District can be carried out by the Rote Ndao District Culture and Tourism Office.

The efforts to increase tourism promotion through: (1) Promotion of tourism by utilizing information technology through both print and electronic media. (2) To undertake tourism promotion trips both within the region, outside the region and abroad; (3) Cooperation with a Travel Bureau (BPW). A travel agency is a company that organizes tour package activities and travel agents. (4) Provision of Tourist Information Center (TIC). Provision of Tourist Information Center (TIC) as a solution to help tourists in finding all tourism information, especially tourism in Rote Ndao District.

4) Development Program of the WT (Weaknesses Threats) Strategy

The development program of the WT strategy is to increase Human Resources [10] Tourism experts state that "tourism is high-touch, high-tech and high involvement industry where it is the people who make the difference". Therefore, the preparation of tourism human resources must be a major concern. The steps to improve human resources must be done from two sides, namely quantity and quality. The quantity of human resources must be prepared in order to anticipate the changing trend of the number of tourists. On the other hand, the quality of human resources must be able to accommodate a variety of trends that are increasingly developing tourist characteristics.

\section{CLOSING}

\section{Conclusion}

Aspects of developing a creative economy based on tourism in the tourist area of Rote Ndao Regency include; Aspects of tourism potential that are very supportive such as marine tourism, traditional ceremonies, art, folk craft forms, folklore, natural beauty, But there are also main problems that become weaknesses and threats, including; aspects of infrastructure in the field of tourism that are still limited and even some are not yet available, whereas, aspects of low accessibility due to poor road conditions, limited facilities in the residential environment; limited transportation infrastructure to tourist sites, as well as the lack of maximum promotional efforts and the unavailability of Tourist Information Center (TIC).

Strategies and programs for developing the Creative Economy that need to be carried out in the tourist area of Rote Ndao Regency, include: (a) Structuring the tourist area, (b) Improving the Quality of the Environment, Enhancing the Quality of Social and Cultural Life of the Community, Increasing the quality of creative industry products, (c) Increased tourism promotion by the Tourism and Culture Office of Rote Ndao District, Cooperation with the Travel Bureau (BPW), Provision of Tourist Information Center (TIC), and (d) Improvement of human resources.

\section{Suggestion}

1. The Culture and Tourism Office of Rote Ndao Regency needs to consider paying more attention to the addition of facilities and infrastructure as well as supporting facilities, preserving 
the beauty and nature conservation, increasing promotion activities, installing tourist location guidelines, using tour guides, conducting HR training

2. Need to establish cooperation with various investors and other regions to help develop the potential that exists in each region.

3. The Head of the District and Tourism, Arts and Culture Office are expected to provide guidance to both the manager and the community

\section{REFERENCES}

[1] Salman, Duygu (2010). "Rethinking of Cities, Culture and Tourism within a Creative Perspective" sebuah editorial dari PASOS, Vol. 8(3) Special Issue 2010-06-16

[2] Moelyono, Mauled. 2010. Menggerakkan Ekonomi Kreatif: Antara Tuntutan dan Keutuhan. Jakarta: Raja Grafindo Persada

[3] Wahyuni Triana (2011: 123) Dampak Usaha Ekonomi Kreatif Terhadap Masyarakat Desa Blawe Kecamatan Purwoasri Kabupaten Kediri , Kebijakan dan Manajemen Publik 2303 341X Volume 4, Nomor 1, Januari-April 2016

[4] Yoeti, Oka A (1985). Pengantar Ilmu Pariwisata, Bandung: Angkasa

[5] Roger, Anthea and Judy Slinn. 1998. Tourism Management of Facilities. London: Pitman Publishing.

[6] Sugiyono. 2008. Memahami Penelitian Kualitatif. Bandung: Alfabeta

[7] Muhammad Rakib, 2017, Strategy for Developing Local-Based Creative Economy to Support Tourism Attraction

[8] Munasri. (2004). Menapak Bumi, Menjelajah Alam Karangsambung Untuk Memahami Dinamika Bumi. Kebumen: UPT. BIKK LIPI Karangsambung.

[9] Bothy Dewandaru, 2016, Strategi Dalam Memajukan Industri Kreatif

[10]Smith and Eadington. 1992. Tourism and Alternatives. University of Pennsiylvania. Press.

Philadelphia. 